Соловйова О.В. к. пед.н., старший викладач

\title{
ТЕХНОЛОГІї 3D-ДРУКУ
}

Державний університет інфраструктури та технологій

У статті представлені історичні факти виникнення технології 3Dдруку; зазначена необхідність впровадження новітніх технологій у процес навчання. На наших очах відбувається нова технологічна, інформаційна $i$ комунікаційна револючія в освіті. Інформаційні, комунікаційні, аудіовізуальні, інтерактивні, мобільні, 3D-технології вже створили новий світ - світ Hi-Tесh. Нині вони формують нові види медіа-комунікацій. Дуже швидкий розвиток техніки і технологій останніми десятиліттями вимагає від сучасної людини знань з багатьох галузей наук, використання технічних засобів і технологічних систем, систем зв'язку та обробки інформачії. I будь-який викладач повинен крокувати в ногу з часом, відстежувати технологічні новинки $і$ знайомити з ними свойх студентів, які теж мають бути в курсі поточних новинок виробництва. Отримуючи високу технологічну підготовку, майбутні інженери зможуть вільно користуватися новими 3D-технологіями, які застосовуються на виробництві. Системи 3D-друку надають можливість вдосконалити процес навчання багатьох дисииплін, у тому числі машинобудування, промислового дизайну і архітектури, хімії і географії, археології $і$ біології, медичного моделювання та образотворчого мистецтва. Тож розвиток технології 3D-друку набирає стрімких обертів $i$, скоріш за все, $3 D$ принтер стане однією з невід'ємних частин майбутнього суспільства, охоплюючи при цььому нові галузі. У статті висвітлені детальні методичні рекомендаиії із запуску 3D-принтера та особливості вибору його моделі для успішної роботи. А також надані приклади безкоштовних програм для технічного $3 D$-моделювання, які можна використати у процесі навчання та в майбутній професійній діяльності. Приділена увага і виправленню помилок у роботі 3D-принтера та детально розглянуті етапи виготовлення $3 D$-моделі.

Ключові слова: 3D-технології; розвиток техніки; $3 D$ - друк; програми для технічного $3 D$ - моделювання; вдосконалення процесу навчання

Постановка проблеми. У статті розглядаються значущість впровадження інформаційно-комунікаційних технологій. Використання технології 3D- друку надає змогу створити за короткий період часу не лише прототип необхідної деталі, але й саму деталь або кілька деталей, що 
надасть можливість показати майбутньому інженеру весь процес від проектування до виготовлення виробу.

Ціль статті. Для досягнення нового рівня процесу підготовки майбутніх інженерів необхідно впроваджувати технології 3D-друку, оскільки немає кращого способу допомогти студентам зрозуміти основи якісного дизайну, ніж створення об’ ємного прототипу їх власного виробу або деталі, для оцінки його форми, збирання та функціональної придатності.

Аналіз основних досліджень і публікацій. Як стверджують С. Подолянчук, Р. Гуревич [1], в умовах інформатизації освіти змінюються напрями педагогічної науки, коригується структура і зміст освіти. Сучасні методи навчання, які грунтуються на самостійних формах навчання i роботи з інформацією, поволі витісняють демонстраційні та ілюстративнопояснювальні методи, які широко використовуються традиційною методикою навчання. Паралельно цьому відбувається впровадження в навчальний процес засобів інформаційно-комунікаційних технологій, що дає змогу значно підвищити його якість i зробити більш гнучким, стимулювати студентів до самостійної роботи. В наш час ми є суб'єктами і об’єктами нової технологічної, інформаційної і комунікаційної революції в освіті. Інформаційні, комунікаційні, аудіовізуальні, інтерактивні, мобільні, 3D-технології вже створили світ Hi-Tech, який формує нові види медіакомунікацій [2]. Технологія 3D-друку увійшла в технологічний світ у 1984 році. Чарльз Холл (Charles Hull) розробив технологію друку фізичних 3Dоб’єктів 3 цифрових даних, а в 1986 році він назвав цю технологію стереолітографією і отримав патент. 3 середини 1980-х було винайдено кілька різних способів 3D-друку, але спочатку принтери були великими, дорогими і вельми обмеженими в можливостях. Найбільш поширеною технологією 3D-друку було моделювання методом наплавлення (FDM). У 1990-му вона була поставлена на промислову основу компанією Stratasys, в якій Крамп був співзасновником [3]. 3 часом, розвиток технології 3Dдруку [4] стане однією 3 невід'ємних частин майбутнього суспільства, охоплюючи при цьому нові галузі. Існує багато інформаційних джерел, які висвітлюють види 3D-друку, його особливості, а також медоти усунення помилок в роботі принтера. При створенні моделей не обійтись без технічного 3D-моделювання. Для цього існує велика кількість веб-ресурсів та безкоштовних програм, які можна використати у процесі навчанні та в майбутній професійній діяльності:

Основна частина. Зміни у сфері виробничих технологій зумовлюють необхідність формування у майбутніх інженерів особливих знань, умінь i навичок, якостей i здібностей, що забезпечують їх професійну мобільність i конкурентоспроможність. Для розвитку перерахованих якостей, необхідний високий рівень сформованості геометрографічної компетентності, що досить важко зробити без використання засобів інформаційно-комунікаційних технологій. 
Засоби інформаційно-комунікаційні технології радикально змінюють форму, через це змінюється і зміст подання наукового знання. Практична реалізація нової освітньої парадигми перебуває в прямій залежності від якості технологічного забезпечення. Інформаційні, комунікаційні, аудіовізуальні, інтерактивні, мобільні, 3D-технології вже створили новий світ - світ Ні-Тесh. Нині вони формують нові види медіа-комунікацій [2].

Провідні позиції в розробці та впровадженні нових освітніх проектів повинна зайняти інфраструктура, що забезпечує підготовку викладацьких кадрів. Якщо установи, які готують майбутніх інженерів, хочуть не відставати від процесів швидких технологічних перетворень, то повинні виступити з ініціативою реорганізації навчання. Необхідна розробка нових педагогічних моделей $\mathrm{i}$ нового інструментарію для забезпечення навчального процесу, щоб працівники освіти змогли повною мірою скористатися перевагами впровадження інформаційно-комунікаційних технологій. Крім того, готувати до цього необхідно як студентів вузів, так i викладачів [5].

Бурхливий розвиток техніки і технологій останніми десятиліттями вимагає від сучасної людини знань з багатьох галузей наук, використання технічних засобів і технологічних систем, систем зв'язку та обробки інформації. 3 метою встановлення взаємозв'язків для практики перетворюючої діяльності молоді фахівці потребують знань із суміжних галузей наук.

Будь-який викладач повинен крокувати в ногу з часом, відстежувати технологічні новинки і знайомити з ними своїх студентів, які теж мають бути в курсі поточних новинок виробництва. Маючи високу технологічну підготовку, зможуть вільно користуватися новими 3D-технологіями, які застосовуються на виробництві. Однією з таких технологій є 3D-друк, який дає змогу створити за короткий період часу не лише прототип необхідної деталі, але й саму деталь або кілька деталей, що надасть можливість показати майбутньому інженеру весь процес від проектування до виготовлення виробу.

Загальновизнано, що існує значна прогалина між знаннями $\mathrm{i}$ навичками, які більшість студентів отримують у технічному вищому навчальному закладі і які їм дійсно необхідні для роботи в інформаційному суспільстві.

Саме тому у процес підготовки майбутніх інженерів необхідно впроваджувати технології 3D-друку, оскільки немає кращого способу допомогти студентам зрозуміти основи якісного дизайну, ніж створення об'ємного прототипу їх власного виробу або деталі, для оцінки його форми, збирання та функціональної придатності. Розглядаючи віртуальні креслення CAПР на папері та комп'ютерні 3D-моделі на екрані монітора, практично неможливо виявити неминучі помилки в конструкції. Технології 3D-друку дають змогу студентам безпосередньо взаємодіяти 3 реальними 3D-моделями й отримувати сильну мотивацію до подальшого 
вдосконалення [6].

Розглянемо історію розвитку технологій 3D-друку детальніше.

Технологія 3D-друку увійшла в технологічний світ у 1984 році. Чарльз Холл (Charles Hull) розробив технологію друку фізичних 3Dоб'єктів з цифрових даних, а в 1986 році він назвав цю технологію стереолітографією і отримав патент. Найбільш поширена технологія 3Dдруку, яка називається "моделювання методом наплавлення" (FDM), була розроблена і запатентована Скоттом Крампом (S. Scott Crump) у 1989 році. В 1993 році Массучесетский Технологічний Інститут (MIT - Massachusetts Institute of Technology) патентує “технологію-3D друку", схожу 3 технологією звичайних струменевих принтерів. У 1995 році компанія Z Corporation отримала ліцензію від MIT для використання технології 3Dпринтерів на основі технології 3DP. I тільки в 2005 році Z Corporation випускає Spectrum Z510. Це був перший на ринку кольоровий 3D-принтер з високою роздільною здатністю. У 2006 році відбувся запуск проекту 3 відкритим доступом RepRap, який був спрямований на розвиток самовідтворюваних 3D-принтерів, які можна розповсюджувати та/або змінювати відповідно до ліцензії GNU (General Public Licence).

3D-принтер, винайдений Чарльзом Холлом в 1984 році, є однією 3 форм адитивного виробництва, де 3D-об'єкт створюється шляхом накладання послідовних шарів різнотипних матеріалів. За допомогою 3Dпринтера розробники мають можливість друкувати деталі і механізми 3 декількох матеріалів з різними механічними і фізичними властивостями за один процес накладання. Друк відбувається за попередньо спроектованою CAD-моделлю. Хоча тривимірний друк часто називають магічною технологією, насправді цей процес вимагає величезної кількості завчасної підготовки і подальшої обробки, необхідної для якісного друку.

На сучасному ринку доступна велика кількість конкуруючих технологій для друку 3D-моделі. Їхні основні відмінності стосуються етапу нашарування при створенні виробу. Деякі технології використовують плавлення або розм'якшення робочого матеріалу для виробництва шарів, інші - рідкі матеріали, які застигають за різними технологіями. Двома основними технологіями $є$ лазерна та струменева.

Лазерна технологія:

- лазерний друк - ультрафіолетовий лазер попіксельно засвічує рідкі фотополімери, при цьому вони тверднуть і перетворюються на досить міцний пластик;

- лазерне спікання - у цьому випадку лазер пошарово випалює в порошку з легкосплавного пластику контур майбутньої деталі;

- ламінування - деталь створюється 3 великої кількості шарів матеріалу, які поступово накладаються один на одного, склеюючись між собою.

Струменева технологія:

- застигання матеріалу при охолодженні - друкуюча головка 3D- 
принтера видавлює із сопел на охолоджувальну платформу краплі розігрітого термопластику або іншого робочого матеріалу. Краплі моментально застигають, формуючи при цьому шари майбутнього об'єкта;

- полімеризація фотополімерного пластику під дією ультрафіолетового випромінювання - спосіб, схожий на попередній, але у цьому випадку пластик твердне під дією ультрафіолетової лампи;

- склеювання або спікання порошкоподібного матеріалу - те саме, що і лазерне спікання, але порошок склеюється клеєм, який надходить із сопел 3D-принтера. У цьому випадку можна відтворити забарвлення деталі, використовуючи сполучні речовини різних кольорів.

Системи 3D-друку надають можливість вдосконалити процес навчання багатьох дисциплін, у тому числі машинобудування, промислового дизайну і архітектури, хімії і географії, археології і біології, медичного моделювання та образотворчого мистецтва. Системи об'ємного друку вдосконалюють процес навчання i сприяють поглибленому вивченню студентами дисциплін технологічного циклу.

Отже, розвиток технології 3D-друку [4] набирає стрімких обертів i, скоріш за все, 3D-принтер стане однією з невід'ємних частин майбутнього суспільства, охоплюючи при цьому нові галузі.

Методичні рекомендації із запуску 3D-принтера.

3D-принтер дає змогу студентам розробляти дизайн предметів, які неможливо зробити навіть за допомогою 4-осьових фрезерних верстатів. Створивши свою модель у CAD-програмі i надрукувавши iii на 3Dпринтері, студенти зможуть побачити результати своєї праці. Краще один раз потримати в руках справжню модель, ніж сто разів побачити іiі на екрані комп'ютера.

Втілення ідеї в різнокольоровому пластиковому об’єкті, створеному за допомогою 3D-принтера, - досить тривалий і копіткий процес. Він складається 3 багатьох різних етапів, які повинні взаємодіяти і бути злагодженими:

Перший крок - це створення комп'ютерної 3D-моделі нашої ідеї, цифрового двійника об'єкта, який ми хочемо надрукувати (етап цифрового моделювання).

Другий крок - створення файлу потрібного формату (зазвичай “STL”), що містить всю геометричну інформацію, необхідну для відображення нашої цифрової моделі (етап експортування).

Якщо модель була спроектована не досить ретельно, в ній можуть бути дефекти. Тому можна спробувати виправити їх за допомогою спеціальної програми (етап відновлення полігональної сітки).

Третій крок - перетворення цифрової моделі в список команд, які 3D-принтер може зрозуміти i виконати, які називаються G-код (етап нарізки).

Четвертий крок - дати принтеру список інструкцій, наприклад, через USB-з'єднання з ПК або скопіювати файл на карту пам'яті, яка буде 
прочитана принтером самостійно (етап з'єднання).

П'ятий крок - запустити 3D-принтер і почати друкувати.

Шостий крок - зняти щойно створений об'єкт з робочої платформи, видалити допоміжні частини (тобто підтримуючі опори i/або підкладку), очистити його поверхню (етап кінцевої обробки).

3D-моделювання. Перший крок до друку реального об'єкта - це створення віртуальної цифрової 3D-моделі за допомогою програми, яка досить часто називається САПР (система автоматизованого проектування, $\mathrm{CAD})$. $€$ багато подібних програм для найпоширеніших платформ (Windows, Mac OS X, Linux), деякі з них безкоштовні або навіть мають відкритий програмний код.

Приклади безкоштовних програм для технічного 3D-моделювання, які можна використати у процесі навчанні та в майбутній професійній діяльності:

Google SketchUp [7] - це програма, проста у користуванні, оптимальна для створення простих моделей. Для побудови моделей у SketchUp є можливість малювати ребра і грані, використовуючи декілька простих інструментів, якими можна опанувати протягом короткого часу $\mathrm{i}$ які здатні видавлювати будь-яку плоску поверхню в 3D-форматі. Крім того, вона працює разом 3 Google Earth, 3 якого можна імпортувати масштабні аерофотознімки.

Autodesk тм Inventor Fusion [8] - професійна САПР програма для Win/Mac, безкоштовна для некомерційного використання.

FreeCAD [9] - програма з відкритим вихідним кодом для Win/Mac/Linux 3 можливістю двомірного і тривимірного параметричного моделювання, досить складна для вивчення, але 3 хорошою документацією.

3Dtin - найпростіше 3D-програмне забезпечення, за допомогою якого моделювання можна виконувати безпосередньо в браузері.

Blender [10] - це потужне програмне забезпечення 3 відкритим вихідним кодом для Win/Mac/Linux, оптимізоване для складної анімації $\mathrm{i}$ рендерингу 3D-об'єктів i персонажів. Це потужна програма містить функції, які характерні для високоякісного 3D-програмного забезпечення 3 можливістю експортування в STL та інструментом для створення 3Dскульптур.

OpenSCAD [1111] - це безкоштовне програмне забезпечення для створення 3D-твердотілих об'єктів, доступне для Linux/UNIX, MS Windows i Mac OS X.

Tinkercad - це новий i досить швидкий спосіб виготовлення конструкцій для 3D-принтера. Користуючись лише трьома основними інструментами, можна створити широкий спектр корисних речей. Як тільки проект буде готовий, достатньо завантажити файл STL i розпочинати процес 3D-друку.

Комерційне програмне забезпечення CAПР, таке як AutoCAD, Pro 
Engineer, SolidWorks, програмні пакети Rhino, Мауа, також підходять для проектування 3D-моделей.

Отримання 3D-моделей з Інтернету. Перш ніж почати створювати свої власні 3D-моделі і починати працювати з більш-менш складними програмами, необхідно звернути увагу на вже готові моделі, зроблені іншими користувачами i розміщені в Інтернеті для безкоштовного завантажування.

Приклади веб-ресурсів 3D-моделей:

Thingiverse [12] - ресурс використовується більшістю ентузіастів дешевого 3D-друку як джерело готових моделей i для обміну своїми моделями.

Autodesk 123D [13] - сайт з великою кількістю об'єктів, які можна безкоштовно завантажити після реєстрації. Файли вже у форматі STL.

Shapeways [14] - веб-сайт, що пропонує безліч чудових проектів, завантажених користувачами, але на ньому майже нічого немає у вільному доступі.

3D warehouse [15] - електронне сховище SketchUp з сотнями моделей найрізноманітніших типів об'єктів.

3D via [16] - невелике сховище 3D-моделей, які можна безкоштовно завантажити після реєстрації.

На більшості цих сайтів доступні для скачування файли пропонуються в декількох форматах, що дає можливість легко змінити моделі і підігнати їх під свої вимоги. Вони також можуть слугувати джерелом вправ для вивчення можливостей сучасних програм для 3Dпроектування. Але навіть якщо на сайті $\epsilon$ тільки файли STL, після скачування їх можна імпортувати в програму 3D-дизайну (іноді для цього потрібні спеціальні плагіни) і таким чином отримати можливість змінити ïx перед 3D-друком. Також $є$ змога роздрукувати змодельований 3D-об’єкт у друкарні. Наприклад, компанія Smartprint в Україні надає послуги 3Dдруку, попередньо завантаживши необхідну модель на сайт 17[17]. Ціна буде залежати від кількості витратних матеріалів 3D-об'єкта.

Методичні рекомендації щодо виправлення полігональної сітки [4]. Файл STL, який використовує деякі програмні засоби моделювання, може бути ще не готовий до друку, незалежно від того, наскільки ретельним був процес створення. Навіть під час використання кращих безкоштовних програм для 3D-проектування неможливо уникнути деяких помилок, таких дефектів, як отвори або вивернута поверхня. Це типові проблеми, які майже неминучі під час створення складних моделей, що мають впадини, перетини поверхонь або просто вигнуті поверхні.

Ідеальна 3D-модель, придатна для друку, повинна бути герметичною i монолітною, не порожньою. Ми, звичайно, можемо проектувати такі об'єкти, як вази або порожні об'єкти, але вони фактично завжди мають внутрішню частину, яка тверда і цілісна (навіть якщо це просто тонка стінка). Через це завжди краще перевіряти 3D-моделі на подібні проблеми 
перед нарізкою, наприклад за допомогою безкоштовної програми netfabb Studio Basic [18], яка доступна для Windows, Mac i Linux.

Етап нарізки для 3D-принтера. Цей крок, можливо, найцікавіший у тривалому процесі руху від ідеї до реального тривимірного об'єкта, оскільки детально розкриває роботу 3D-принтера 3 перетворення твердої пластикової нитки в готовий виріб.

Перед друком 3D-модель (збережену або експортовану в STL-файл) слід перетворити в набір інструкцій для принтера (стандартний формат G-код): це завдання називається нарізкою (бо модель “нарізається" на безліч тонких горизонтальних шарів, які будуть послідовно надруковані) i виконується за допомогою комплексу програм, які називаються слайсерами.

На цьому етапі 3D-модель “нарізається" на безліч горизонтальних шарів, перетворюючись у стопку тонких деталей, кожна 3 яких обробляється окремо. Щоб розрахувати кращий шлях сопла при укладанні розплавленої пластмаси в потрібних місцях; повторюючи цей маршрут, друкуюча головка практично проробляє таку ж роботу (тобто шар за шаром).

Вибір пластикових витратних матеріалів (нитка/пруток). Нині існують два види пластика, які широко використовуються в недорогих, менш поширених 3D-принтерах [4].

Пластикову нитку виробляють у двох стандартах: діаметром 1.75 мм i 3.0 мм. Трьохміліметрова нитка - більш старий стандарт, він поступово витісняється 1.75-мм, який легше видавлюється і краще управляється.

Полілактид (PLA). Найбільш поширена пластмасова нитка, зроблена з полімолочної кислоти (або полілактиду (PolyLactide Acid) - скорочено PLA). Це біорозкладний i екологічний пластик, отриманий 3 крохмалю. Температура плавлення в межах $180-230^{\circ} \mathrm{C}$. Під час друку він не має неприємного запаху, його пари безпечні, тому немає потреби у застосовуванні спеціальних заходів безпеки або примусової вентиляції. Предмети, надруковані за допомого PLA, міцні, але не можуть експлуатуватися за високих температур.

АБС (ABS). Другий, найбільш поширений матеріал для друку, виготовлений 3 акрилонітрил бутадієн стиролу (Acrylonitrile Butadiene Styrene), або АБС-пластик. Цей пластик виготовляється з нафтопродуктів i використовується для різних цілей. Його пари мають неприємний запах i навіть вважаються небезпечними для здоров'я, тому рекомендується використовувати примусову вентиляцію для відводу продуктів горіння пластику, коли друк АБС-пластику здійснюється протягом тривалого часу. Температура плавлення ABS $210-260^{\circ} \mathrm{C}$.

Перевага ABS порівняно 3 PLA полягає в тому, що отримувані об'єкти більш міцні i менш крихкі, можуть витримувати високі температури. Нитка ABS зазвичай доступна в багатьох кольорах, включаючи золотий, срібний і навіть колір, який змінюється під впливом 
температури.

Нейлон (Nylon). Цей пластик має кілька цікавих особливостей, серед них гнучкість, легкість і стійкість до хімічного впливу. Він повинен видавлюватися за більш високої температури порівняно 3 PLA або ABS (приблизно $245^{\circ} \mathrm{C}$ ), але під час розплавлення не має шкідливих парів або запахів. Використовується для друку механічних деталей, яким необхідна висока стійкість до пошкоджень і дуже низьке поверхневе тертя. Вартість нейлонової нитки в два рази більша, ніж вартість PLA або ABS. Сдиний доступний колір - білий.

Полікарбонат (Polycarbonate - PC). Це дуже міцний і довговічний пластик 3 високою оптичною прозорістю $\mathrm{i}$ високою температурою плавлення (приблизно $270-300^{\circ} \mathrm{C}$ ). Незважаючи на це, використовується в багатьох промислових виробництвах (наприклад, CD та DVD-диски зроблені 3 полікарбонату). Перші тести 3 дешевими 3D-принтерами почалися тільки в 2012 році і поки є лише кілька виробників РС нитки, що продають їі досить дорого (приблизно 90\$ за кілограм).

Запуск 3D-принтера. Принтер повинен бути ретельно підібраний i готовий до запуску; нитка відповідного діаметру, типу і кольору для цього принтера; файл g-коду, створений програмою-слайсером, належним чином сформований згідно з властивостями, які ми хотіли б отримати для нашого об'єкта. Увімкнувши принтер, з'єднаємо його з комп'ютером і почнемо процедуру калібрування:

- перша проблема, яку треба вирішити, - це визначення правильних параметрів з'єднання: більшість принтерів, незважаючи на підключення через USB, всередині використовують чип «USB-to-serial» для забезпечення послідовного потоку даних (у стилі RS-232) до центрального процесора, і це означає, що швидкість послідовного каналу, кількість біт старт/стоп і процедура підтвердження зв'язку повинні відповідати правильним значенням;

- коли зв’язок встановлено, ми можемо почати посилати команди gкоду принтера, щоб перевірити, чи працює все належним чином. Процедура калібрування передбачає перевірку всіх кінцевих датчиків, датчиків температури (термісторів) і крокових двигунів;

- коли всі ці перевірки пройдені, можемо зробити вирівнювання підставки для друку. В ідеалі - це платформа, яка є максимально плоскою і паралельна осям, що рухаються у всіх напрямках друкуючої головки. Щоб домогтися цього, користувач повинен рухати головку в усіх напрямках, порівнюючи іiі вертикальне положення з платформою і правильним рівнем останньої;

- після вирівнювання платформа повинна бути ретельно очищена i покрита необхідним видом поверхні: це може бути один або кілька шарів синьої стрічки (для PLA) або каптонової стрічки (для ABS), або відповідним матеріалом для інших видів пластмаси;

- використовуючи нитку ABS, необхідно попередньо нагріти 
підставку для друку (платформу друку);

- наступний крок вимагає завантаження нитки: для цього треба нагріти друкуючу головку (тобто сопла) і запустити механізм екструдера (або вручну, або шляхом активації крокового двигуна екструдера). Після видавлювання невеликої кількості пластмаси ми будемо впевнені, що сопло заповнене пластмасою і готове до друку;

- тепер необхідно завантажити g-код для об'єкта, який ми хочемо надрукувати на принтері;

- безпосередньо сам процес друку на 3D-принтері.

Друк невеликого порожнього об'єкта шириною кілька сантиметрів може тривати приблизно 10-20 хвилин, тоді як для об'єкта розміром 3 яблуко час друку може збільшитись до однієї години і навіть більше (це залежить від роздільної здатності, заповнення та швидкості принтера). Друк великих об'єктів може зайняти 10 годин, а якщо вони досить складні або із суцільним заповненням, то процес може тривати 20 і більше годин.

Після того, як принтер надрукував об'єкт, необхідно дати йому кілька хвилин, щоб всі його частини охололи, а у випадку з ABS буде набагато легше відокремити об'єкт від основи. Потім за допомогою гострого ножа або леза різака, необхідно видалити підкладку i/aбо підтримуючі опори.

Доступний тривимірний настільний друк, незважаючи на те, що перебуває на початковій стадії розвитку, швидко формується, мабуть, 3 безмежним потенціалом. Ми сподіваємося, що ця ультрасучасна 3Dтехнологія відкриє нові виміри для науки і освіти, і справить помітний вплив на технологічний і суспільний процес.

Висновки та перспективи. 3D-друк $є$ відмінною альтернативою традиційним способам виготовлення прототипів, що істотно економить час і кошти в дослідно-конструкторських розробках. Можливості технології 3D-друку повсюдно використовують у професійному середовищі розробники, а тепер все частіше застосовуються в освітніх і науководослідних програмах технічних навчальних закладах. Знайомство студентів 3 технологією об'ємного друку сприятиме зміцненню їхнього інтересу до майбутньої професії і надасть можливість вже сьогодні доторкнутися до технологій майбутнього [19].

За технологіями 3D-прототипування велике майбутнє. Не так давно люди бажали мати комп'ютери у власних будинках, і це здійснилося. Потім люди мріяли про мобільний зв'язок “на ходу”. Мобільні телефони 3 обчислювальною потужністю, як у настільних комп'ютерів, з'явилися кілька років тому. Що ж до 3D-принтерів? У найближчому майбутньому вони стануть технікою для дому. 3D-друк стає все більш доступним. 3 його допомогою можна друкувати запасні частини для зламаної техніки, замовляти компоненти, об'єкти власного дизайну. Зараз активно розширюється цифрова база даних $3 \mathrm{D}$-моделей. За допомогою $3 \mathrm{D}-$ принтерів можна робити складні конструкції у віддалених районах (навіть 
у космічному просторі) або в економічно менш розвинених країнах [20].

3D-друк - це явище вже не стільки технологічне, скільки економічне і соціальне. Так само, як декілька десятиліть тому, поява персонального комп'ютера підштовхнула суспільство до переходу від колективного створення та споживання інформаційного продукту до індивідуального, 3D-друк стає найважливішим елементом нової індустріальної революції, що полягає в індивідуалізації виробництва.

\section{Література}

1. Подолянчук $C$. Інформаційно-комунікаційні технології під час вивчення курсу “Опір матеріалів” / С. Подолянчук, Р. Гуревич // Трудова підготовка в закладах освіти. - 2002. - № 4. - С. 47-52.

2. Кувшинов С. В. 3D в освіті: захоплені очікування та реальні тривоги [Електронний ресурс] / С. В. Кувшинов, Г. Н. Усков. - Назва 3 екрану. - Режим доступу : http://www.gosbook.ru.

3. [Електронний pecypc]. - Режим доступу : http://en.wikipedia.org/wiki/Stratasys

4. Доступная 3D-печать для науки, образования и устойчивого развития. / ред. Э. Канесса, К. Фонда, М. Зенаро // Международный центр теоретической физики Абсуд Салам. - Триест, Италия : Изд. МТЦФ Отдел научных разработок, 2013. - 192 с.

5. Информационные и коммуникационные технологии в подготовке преподавателей. Руководство по планированию. - Division of Higher Education, ЮНЕСКО, 2005. - $286 \mathrm{c}$.

6. Шпильовий Ю. В. Нові види медіа-комунікацій в системі педагогічної освіти (на прикладі 3D-технологій) / Ю. В. Шпильовий // Стратегія якості в промисловості і освіті: IX міжнародна конференція. - Том 3 / упор.: Т. С. Хохлова, В. А. Хохлов, Ю. А. Ступак. - Дніпропетровськ-Варна, 2013. - С. 550-553.

7. [Електронний ресурс]. - Режим доступу : http://www.sketchup.com

8. [Електронний pecypc]. - Режим доступу : http://labs.autodesk.com/technologies/fusion

9. [Електронний ресурc]. - Режим доступу : http://www.freecadweb.org

10. [Електронний ресурс]. - Режим доступу : http://www.blender.org

11. [Електронний ресурс]. - Режим доступу : http://www.openscad.org

12. [Електронний ресурс]. - Режим доступу : http://www.thingiverse.com

13. [Електронний ресурс]. - Режим доступу : http://www.123dapp.com/Gallery/

14. [Електронний pecypc]. - Режим доступу : http://www.shapeways.com/gallery

15. [Електронний pecypc]. - Режим доступу : http://sketchup.google.com/3dwarehouse/ 
16. [Електронний ресурс]. - Режим доступу : http://www.3dvia.com/users/models

17. [Електронний pecypc]. - Режим доступу : http://3dsmart.com.ua/

18. [Електронний pecypc]. - Режим доступу : http://netfabb.com/basic.php

19. [Електронний ресурс]. - Режим доступу : http://www.printcad.ru.

20. [Електронний ресурс]. - Режим доступу : http://baltexim.ru/

\section{ТЕХНОЛОГИИ 3D-ПЕЧАТИ}

\section{Соловьева О.В. Государственный университет инфраструктуры и технологий}

В статье представлены исторические факты возникновения технологий 3D-печати; указана необходимость внедрения новейших технологий в процесс обучения. На наших глазах происходит новая технологическая, информационная и коммуникационная революция в образовании. Информационные, коммуникационные, аудиовизуальные, интерактивные, мобильные, 3D-технологии уже создали новый мир - мир $\mathrm{Hi}$-Tech. Сейчас они формируют новые виды медиа-коммуникаций. Очень быстрое развитие техники и технологий в последние десятилетия требует от современного человека знаний во многих отраслях наук, тспользование технических средств и технологических систем, систем связи и обработки информации. И любой преподаватель должен идти в ногу со временем, отслеживать технологические новинки и знакомить с ними своих студентов, которые тоже должны быть в курсе текущих новинок производства. Получая высокую технологическую подготовку, будущие инженеры змогут свободно пользоваться новыми 3D-технологиями, которые используются на производстве. Системы 3D-печати дают возможность усовершенствовать процесс обучения многих дисциплин, в том числе машиностроения, промышленного дизайна и архитектуры, химии и географии, археологии и биологии, медицинского моделирования и изобразительного искусства. А значит развитие технологии $3 \mathrm{D}-$-печати набирает стремительные обороты и, скорее всего, 3D-принтер станет одной из неотъемлимых частей будущего общества, охватывая при этом новые отрасли. В статье освещены детальные методические рекомендации по запуску 3D-принтера и особенности выбора его модели для успешной работы. Также даны варианты бесплатных програм для технического 3Dмоделирования, которые можно использовать в процессе обучения и будущей профессиональной деятельностиякі. Уделено внимание и способам исправления ошибок в работе 3D-принтера и детально рассмотрены этапы изготовления 3D-модели.

Ключевые слова: 3D-технологии, развитие техники, 3D- печать, 
программы для технического $3 D$ - моделирования, усовершенствование прочесса обучения

\title{
3D PRINTING TECHNOLOGY
}

\author{
O. Soloviova \\ State University of Infrastructure and Technologies
}

The article deals with the historical facts of the advent of 3D-printing technology and explains the need to implement brand-new technologies into the process of teaching.

We are witnessing new technological, information, communication revolution in education. A new world of Hi-Tech has been created by information, communication, audio and visual, interactive, mobile and $3 D$ technology. Now they are forming new ways of media communications. During the last decades, the development of engineering and technology demands lots of knowledge in different fields of science, as well as the ability to use technical means, technologic, communication and information processing systems. Nowadays every lecturer should keep up to date monitoring technological innovations, introducing them to students. After reaching high technological level, future engineers will be able to use new technologies in their workplace. $3 D$-systems allow us to improve the process of teaching in many fields, such as mechanical engineering, industrial design and architecture, chemistry and geography, archeology and biology, medical modeling and art. Therefore, the development of 3D-printing technology is gaining momentum, and 3D-printer will probably become an integral part of future society embracing new areas.

The article highlights detailed methodological recommendations for choosing 3D-printer models and launching it for successful functioning. The author suggests some examples of 3D-modeling software, which can be used while teaching and in future working activities. The stages of 3D-model production and the problem of fixing errors in 3D-printer functioning are also considered

Keywords: $3 d$ - technology; development of technology; 3D-printing; applications for technical 3D modelling; improving the learning process 